ПУБЛІКАЦІЯ ДОКУМЕНТІВ

ISSN 2519-2523 (print)

DOI: $10.18524 / 2519-2523.2020 .15 .218685$

УДК 94(477.74):34 “1828-1868”

\title{
CRIMES, PUNISHMENT AND THEIR EXECUTION IN THE VILLAGES OF THE DANUBE (NOVOROSIYSKY) COSSACK ARMY (1828-1868)
}

\author{
Olena Bachynska \\ ORCID: https://orcid.org/0000-0003-0496-5742 \\ DSc (History), Professor \\ Odessa I.I. Mechnikov National University \\ 2, Dvoryanska Str., Odessa, 65082, Ukraine \\ Olena_an@ukr.net
}

The question of the system of punishments, their adequacy to the crimes committed has become important today. Discussion of this issue is important not only for Ukraine but also for most countries of the world. This changes the view of both the crimes themselves and their assessment. The institution responsible for the execution of sentences imposed under the legislation currently being modernized in Ukraine is called the penitentiary service. Its operation and effectiveness often depend not only on global rules, codes and practices, but also on local traditions in the penitentiary system and their enforcement. Certain crimes of a moral and ethical nature are difficult to assess in terms of legal norms, and at different times may not be considered as crimes. The study of these traditions actualizes the historical experience that needs to be studied, in particular on the territory of Ukraine, in such organizations as Cossack societies and Cossack troops. These were paramilitary structures that have clearly defined rights, responsibilities, a system of punishment and their execution. However, even in these structures there were deviations from national rules. In this regard, the objectives of our publication is to show, on the example of one archival case, the causes of crimes, their nature and form, the figures of prosecuted Cossacks, punishments and their implementation that existed in real life of the Cossacks, one of the last Cossacks formations of the XIX century on the territory of modern Ukraine - the Danube (Novorossiysk) army.

It was ascertained that the organization that considered the violations and served as a court in the Danube Cossack Army was a commission of the Military Court. It was determined that the main reasons for the lawsuits were the Cossacks' protests against the arbitrariness and abuse of officers and military officials, which manifested themselves in runaways, complaints, and so on. In some case, Officers and Cossacks were also the subject to trial for drunkenness and violation of moral and ethical norms.

Key words: Military court commission, escape, Danube (Novorossiysk) Cossack army.

Олена Бачинська

ORCID: https://orcid.org/0000-0003-0496-5742 Доктор історичних наук, професор, зав.кафедри історії України Одеський національний університет імені I.I. Мечникова, Вул. Дворянська, 2, 65082, Одеса, Україна Olena_an@ukr.net 


\section{ЗЛОЧИНИ, ПОКАРАННЯ ТА ЇХ ВИКОНАННЯ У СТАНИЦЯХ ДУНАЙСЬКОГО (НОВОРОСІЙСЬКОГО) КОЗАЦЬКОГО ВІЙСЬКА (1828-1868 pp.)}

У статті розглядаються основні види злочинів та покарань, які розглядала комісія Військового суду при Військовому правлінні Дунайського (Новоросійського) козаџького війська. 3'ясовано, щзо в багатьох випадках до втеч зі служби козаків провокували дії офіцерів, які, як правило, не несли за такі провокації жодних покарань. У додатках до статті публікуються документи однієї зі справ козака Івана Дульдієра, вчинки якого Комісія розглядала не одноразово.

Ключові слова: злочини, козак, Дунайське військо, комісія Військового суду.

Важливого значення на сьогодні набуває питання про систему покарань, їх співвідношення та адекватність злочинам, що були скоєні. Обговорення даного питання є важливим не лише для України, але й для більшості країн світу. Це змінює погляд, як на самі злочини, так і на їхню оцінку. Інститут, що відповідає за виконання покарань, які були покладені за законодавством, що на сьогодні модернізується в Україні, має назву пенітенціарна служба. Ї̈̈ діяльність та ефективність часто залежить не лише від загальносвітових правил, кодексів і практик, але й від місцевих традицій у системі покарань та їхнього виконання. Окремі злочини морально-етичного характеру важко підлягають оцінці з точки зору правових норм, і в різний час можуть злочинами не вважатися. Актуалізує вивчення цих традицій історичний досвід, який треба вивчати, зокрема, на території України, в таких організаціях, як козацькі товариства і козацькі війська. Це воєнізовані структури, які мають чітко визначені права, обов'язки, систему покарань та їх виконання. Однак, навіть, в цих структурах мали місце відхилення від загальнодержавних правил. У зв'язку 3 цим, метою i завданням нашої публікації є показати, на прикладі однієї архівної справи, причини злочинів, їх характер і форми, постаті притягнених до відповідальності козаків, покарання та їхні виконання, що існували в реальному житті козаків, одного 3 останніх козацьких формувань XIX ст. на території сучасної України - Дунайському (Новоросійському) війську.

Дунайське козацьке військо було створене у 1828 р. із задунайських запорожців, колишніх козаків Усть-Дунайського Буджацького, Чорноморського військ, волонтерів російсько-турецьких війн кінця XVIII - початку XIX ст., відставних солдат і коронних циган. У середині 50-х років XIX ст. військо нараховувало понад 12 тис осіб, які проживали в дев'яти станицях і хуторах: Миколаївка-Новоросійська, Акмангіт, Старокозачя, Волонтирівка, Фараонівка, Михайлівка, Каїри (тепер Татарбунарський, Білгород-Дністровський, Саратський райони Одеської області та район Штефан Воде Рсспублікн Молдова). Загальне керівництво здійснював новоросійський та бессарабський генерал-губернатор. Місцеве управління здійснювалося Військовим правлінням на чолі з наказним отаманом.

За Положенням при Військовому правлінні працювала комісія Військового суду. Це не був постійно діючий орган. Комісія, збиралась в разі необхідності, за розпорядженням наказного отамана. Вона складалась 3 презуса, трьох асесорів, аудитора та писаря. Комісія розглядала суто військові справи, що торкалися службових та позаслужбових порушень військових чинів. Про стан справ вона доповідала Правлінню щотижня. Інші справи - цивільного та кримінального характеру - розглядалися місцевими повітовими судовими органами за присутності представника від війська. Після закінчення справ дії комісії припинялись, але аудитор залишався працювати у Військовому правлінні [8]. 
Станичні правління були виборними органами. Вони складались з отамана, двох суддів, писаря та фельдшера. До обов'язків станичних правлінь входила охорона станичного майна та кордонів, благоустрій, справне утримання іменних і чергових списків, метричних книг, особливо перепису малолітніх та щорічні звіти про стан станиць Військовому правлінню. В окремих невеликих хуторах, де не було станічних правлінь, призначались приказний та суддя 3 декількома десятськими, які мали поліцейські функції й підпорядковувались відповідним станичним правлінням. Крім того, в станиці Каїри ще обирався урядник для нагляду за громадським порядком [9; 11, арк. 28].

Слід зазначити, що жорстокий військовий регламент і постійний контроль військової адміністрації не давав змоги козацькому протесту виливатися у відверті зіткнення та мав, переважно, пасивний характер.

Одним з розповсюджених виразів протесту були втечі козаків зі служби та станиць. Ця форма носила хронічний характер і викликала неабияку стурбованість адміністрації.

Вже на початку формування війська у вересні 1838 р. хорунжий Д.Чорнобай повідомляв полковнику Семену Чолобітчикову про те, що він привів до ст. Старокозачя й Акмангіт близько 200 козаків, станичники звинуватили його в тому, що він привласнив надані їм кошти та провіант і відмовлялись утримувати козаків. Через це деякі козаки не “ївши по два й по три дні тікали за Дунай” [3, арк. 243; 4, арк. $52,81]$. В подальшому втечі козаків продовжувались.

Джерела зберегли чимало свідчень про факти зловживань і сваволі офіцерів та інших військових чиновників, в залежності від яких опинялися служилі козаки. Це викликало незадоволення козаків i, як внаслідок, порушення дисципліни, скарги, втечі або відкриті протести. Подібні вчинки розслідувались і давали роботу комісії Військового суду. Так, осавул Данило Голобородько і хорунжий Дем'ян Чорнобай “обмежували козаків у продовольстві», осавул Микола Фролов «робив козакам різні утиски». Зокрема, ці офіцери не додали їм продовольства на 1175 крб., продавши його «стороннім особам» [5, спр.19, арк. 146, 329]. Комісар 12-го класу Чорниський «використовував для партикулярних робіт» козаків, яких було йому виділено для охорони провіантних магазинів, а деяких «карав тілесно без пощади». Сотник Олександр Білий недодав козакам фуражних грошей та платні, карав невдоволених батогами [2, арк. 5, 47, 127, 137].

Козак Діордій Лупул, який втік $з$ дев’ятьма товаришами 3 митного Ізмаїльського кордону, пояснив так причини, що штовхнули його на такий вчинок: «... скільки вже служу, а не одержав повної платні і зараз не сподіваюсь отримати іiі, тому що вираховують за різні амунічні речі і повинен залишатися знову без.... нової одежі та обувки взамін старої». Його товариші підтвердили, що Лупул «вкрай потребував одежі і обувки так, що коли заступав на варту, то одягав полатані постоли» [5, спр.45, арк. 29, 35, 63-64].

У 1835 р. втік Дмитро Драгоман разом з трьома козаками, яких він охороняв на гауптвахті та які були арештовані за другу й четверту втечі. За розпорядженням новоросійського та бессарабського генерал-губернатора Д. Драгоман після того як його спіймали, був покараний 100 ударами палок. Арештований в тому ж році за другу втечу козак Іван Блинар був прогнаний крізь стрій в 500 чоловік [7, спр. 9, арк.10 зв.]. Сваволю над козаками чинили не лише офіцери на службі, але й чиновники в станицях. В 1836 р. козак ст. Миколаївка Іван Сгоров скаржився наказному отаману, що станичний пристав урядник Ясський вимагав, щоб він косив 
сіно для нього. Єгоров відмовився оскільки «мав заняття у своєму господарстві. Так продовжувалось декілька разів. Ясський не забув відмови і без всякої провини постійно переслідував Єгорова, арештовував і бив» [5, спр. 18, арк. 423].

Початок багатьом втечам 3 війська поклала діяльність наказного отамана Станіслава Василевського. У червні 1836 р. він писав новоросійському та бессарабському генерал-губернатору про те, що при формуванні Дунайського війська «багато козаків вступили під чужими прізвиськами та ім'ям», в зв'язку 3 тим він просив дозволу провести перевірку та поновити їх справжні прізвища. М. Воронцов схвалив ініціативу отамана. Так, у Військовому правлінні 5 червня 1836 р. виникла ціла справа під назвою «Про перейменування козаків, записаних до Дунайського війська під чужими іменами та прізвищами», вона тривала до жовтня 1844 р. [7, спр.12, арк.15; спр. 30, 1-139]. У багатьох козаків і у нелегального елемента, який ховався у станицях і сусідніх 3 ними селищах, ця перевірка викликала зрозуміле обгрунтоване занепокоєння. Серед них поширились чутки про те, що втікачів будуть повертати колишнім господарям або на старе місце мешкання. Виходом 3 такого становища для багатьох була лише втеча. За переліком на початок 1837 р. за цією справою у війську було перейменовано 77 осіб, зокрема: в кінному полку 41, пішому -25, станицях - 11 [7, спр.11, арк.1-4].

Втечі козаків продовжувались протягом усього часу “перебірки”. В 1840 р. був заарештований за втечу зі служби козак ст. Старокозачої Терентій Красовський. На допиті з'ясувалось, що справжнє його прізвище Олексій Марченко. Було наказано покарати його за втечу і «за неправдиве присвоєння собі дворянського походження». В 1842 році з Ізмаїльського митного кордону втекла за кордон група козаків 4-ї сотні 2-го Дунайського полку. Згодом наказний отаман Івана Гангардт пояснив це так: «втекло до 12 чоловік раптом. Було слідство за скаргою на утиски, але скарги не підтвердилися. Винні піддані «примірному розстрілу і пробачені. Троє померли» [5, спр. 145, арк. 39; спр.30, арк. 36-36 зв.]. Через такі втечі з кордону Дунайський полк був замінений Донськими сотнями.

Однак, відверто кажучи, наказний отаман погрішив проти істини. Утиски дійсно були і призвели до того, що у січні-лютому 1844 р. втекло за Дунай відразу 38 козаків. Це викликало серйозне занепокоєння в Управлінні новоросійського та бессарабського генерал-губернатора. Слідство було доручено капітану корпусу жандармів Міцулі і старшому ад’ютанту чергування генерал-губернатору майору Орлаю 2-му. Воно відкрило цілу низку непривабливих фактів свавілля, насильств та зловживань. Тут були і розкрадання коштів, наданих на довольство козакам, і утиски станичних отаманів, в тому числі і призначення козаків на службу не в чергу, стягнення невстановлених коштів за випас худоби козаками на станичних землях, $\mathrm{i}$ примущення виконувати, «не в залік» громадські повинності і багато іншого. Проте, ті козаки, яким не вдалося втекти, були схоплені, і як в 1842 р. були наказані «примірному розстрілу». Один 3 таких втікачів, опинившись за Дунаєм в м.Тульчі Корній Білий пригадував: «А тоді ще раз перевірка була: генерал Василевський був над дунайськими козаками ... ну, й перебирали всіх - хто панський був, так і панам відправляли, голови голили наполовину, а хто стара людина, то і пів бороди голили. Багато тоді народу сюди, в Добруджу, перейшло». Таке знущання, за свідоцтвом капітана Міцулі, було заподіяно за наказом отамана козакам Мартину Пилипчуку та Іллі Бедуненку [10, с. 270-272, 614].

Особливе занепокоєння військової адміністрації викликала можливість втеч козаків під час евакуації за Буг у зв'язку з очікуваним в період Кримської війни вторгненням ворога в Бессарабію. Командування тримало в таємниці намір оселити 
дунайців у військові поселення. Наказний отаман у бесіді 3 головнокомандуючим Південної армії Горчаковим зазначив, що «козаки жахаються i самої назви військового поселення; якщо б вони уявили, що їх намагаються повернути в регулярне військо - вони б усі повтікали. - Куди? За Дунай!» [5, спр.145, арк. 37-38]. Хоча переселення не відбулося, втечі з війська продовжувались і надалі, майже до самої його ліквідації, але в менших розмірах.

В 1857 - 1858 рр., наприклад, в комісії Військового суду війська на розгляді знаходилось дев'ять справ про втечі козаків зі служби, в тому числі справа козака Самійла Тищенка, якій втікав чотири рази і був засуджений до каторжних робіт та справи Максима Швачки і Григорія Фонарія за другу втечу [5, спр.169, арк. 45-46]. На початку грудня 1869 р. за всіма військовими підрозділами, станицями і хуторами втікачів нараховувалось 255 осіб [5, спр. 204, арк.48-178].

Цікавий матеріал дає справа Івана Дульдієра, який втік з молдавського кордону в 1864 р. До цього часу він вважався бездоганним козаком. Проте умови служби, утиски та причипки, іноді навіть «соромні» з боку керівництва полку, змусили його втікти. В цій справі є свідчення самого Івана Дульдієра, його керівників та вирок суду (див. документи до публікації). Подібне зробив і козак Дунайського полку № 1 Степан Деревицький, який в 1865 р. втік вже утретє. Перейшов до Молдавії, де записався під ім'ям Степана Новженка в рекрути. За вироком комісії Військового суду його було засуджено до шести років в арестантські роти [6, арк.128-141].

Причиною виникнення судових справ було також пияцтво і порушення норм морально-етичного характеру, але такі випадки комісія Військового суду розглядала разом із церквою. Так виникла ціла справа про незаконне життя козака ст. Михайлівка І.Голіца з М.Болазановою. Церква наклала на них єпитимію на 7 років та одружила [1, с. 873; 5, спр.58]. Справа про незаконне співжиття судді ст. Новотроїцької Гинкула та його сина Івана 3 вдовою козачкою Ф.Горбельщуковою розглядалась декілька місяців комісією Військового суду, було опитано 12 свідківкозаків станиці, внаслідок чого батька та сина Гинкулів було виправдано, а справа про поведінку вдови передана для подальшого розгляду в Кишинівську духовну консисторію [7, спр. 33, арк.86-87].

Отже, організацією, що розглядала порушення, виконувала функції суду у Дунайському козацькому війську була комісія Військового суду. Основними причиними виникнення судових справ були протести козаків проти свавілля та зловживань офіцерів і військових чиновників, що виявлялись у втечах зі служби, скаргах тощо. Суду підлягали також офіцери та козаки за пияцтво і порушення норм морально-етичного характеру.

Документи:

Документ №1. Комісія Військового суду при Новоросійському козацькому війську. 20 лютого 1868 р. Станиця Миколаӥвка-Новоросійська.

Отставному Войсковому старшине Петровському

Подсудимый Иван Дульдиер на допросе показал, что заступил на службу в 1861 году в 5-ю сотню в с. Дивизия, поначалу старшиной был Педашенко, затем Петровский. Педашенко уходя ${ }^{2}$ сказал Петровскому, что бы предоставить Дульдиеру положенный отпуск летом, но Петровский не предоставил ему летом 1861 года отпуск $^{3}$, а другие казаки только заступили - ходили в отпуск по три раза.

\footnotetext{
2 в январе 1862 года

3 [«хотя бы переодеть рубашку, которая на нем уже сгнила»] (арк.123)
} 
При Петровском выдавали неполный провиант, в каждом пайке недоставало по 10 фунтов муки, и на меру, а не на вес, как при Педашенко.

За эти слухи он ${ }^{4}$ винил Дульдиера, как старого казака, оказывал ему придирки на службе ${ }^{5}$ чему были свидетели.

В июне 1862 года Дульдиер находился на кордоне № 90. За старшего из казаков был Василий Горбенко. Он его ${ }^{6}$ попросил отпустить к родственникам в село Монаши, где хотел поменять рубашки. С ним просился Алексей Паладий, они сказали, что до утра вернуться. Но родственников он не нашел, зашел в корчму, подгулял, и уехать не мог, заснул около корчмы. Затем за ним приехали казака и Петровский потребовал к себе, где сказал, что теперь он пойман, так как без разрешения уехал. Не желая подводить Горбенка он промолчал, однако, наказали только Дульдиера.

Обычно за такие проступки казаков арестовывали на сотенном дворе при конюшни, его же особенно торжественно, при трех или четырех казаках с шашками наголо отправили под арест в этапный дом в село Дивизия. Узнал он о том, что сотенный командир хочет отдать его под суд и он задумал бежать.

\section{Документ №2. Свідчення сотенного командира Петровського. Вересень 1862 р.}

Показания сотенного командира Петровского о том, что Дульдиер просил отпуск не в станицу, а в Кишиневский или Оргеевский уезд, где была его жена, так как кратковременного отпуска было мало, Петровский ходатайствовал у командира полка, который разрешил дать отпуск в июне, когда смениться с кордона, и лошади перейдут на подножный корм. Он просил еще раз, но я не могу лезть к командиру полка беспрерывно, как он ко мне. .........

Петровский показал, что Дульдиер ушел с кордона без рзрешения и он не хотел его отдать под суд, а лишь дал распоряжение проспаться.

\section{Документ №3. Справа про периу втечу зі служби та інші незаконні вчинки Івана Дульдісра.}

В комиссию Военного суда, которая создана при Войсковом правлении Новороссийского козачьего войска.

\section{Сентенция}

После побега Дульдиер бродяжничал, затем под именем Семена Доброжана был сдан наемщиком в рекруты в Кишиневском рекрутском присутствии и зачислен в 11-й пехотный резервный батальон, расположенный в Херсоне, прослужив с 22 апреля по 18 мая 1866 года он бежал, взяв некоторые казенные вещи, прибыв в июне в город Николаев был задержан полицией.

Признать виновным в:

1. Побеги, длившимся 4 года

2. В сокрытии фамилии во время побега

3. В найме в рекруты

4. В несправедливом обвинении сотенного командира Петровского.

\section{Документ №4. 3 формулярного списока Івана Дульдієра.}

43 года, на службу вступил 1 мая 1846 году Новороссийский казачий №1 полк, был в походе на Кавказе.

\footnotetext{
${ }^{4}$ Петровский

${ }^{5}$ [«хотя тот был старый казак и знал службу многих молодых лучше»] (арк.123)

${ }^{6}$ Горбенка
} 
Имеет бронзовую медаль на Андреевской ленте в память войны 1853-1856 годов, нашивки за беспорочную выслугу 10 лет.

До побега аттестовался отлично.

HАРМ. - Ф. 1048. - On.1. - Спр. 25. Арк. 123 - 260.

\section{Джерела та література:}

1. Бурьянов А. Историко-статистическое описание церкви и прихода селения Волонтировки, бывшей казачьей станицы Аккерманского уезда // Кишиневские епархиальные ведомости. 1877. - № 20.

2. Державний архів Одеської області. - Ф. 1. - Оп 218 (1831). - Спр. 8.

3. Державний архів Одеської області. - Ф. 1. - Оп 218 (1828). - Спр. 9а.

4. Державний архів Одеської області. - Ф. 1. - Оп 218 (1832). - Спр. 4.

5. Комунальна установа “Ізмаїльський архів". - Ф. 755. - Оп. 1. - Спр. 98.

6. Національний архів Республіки Молдова. - Ф. 1048. - Оп.1. - Спр. 150.

7. Центральний державний історичний архів у м.Київ. - Ф.245. - Оп.1.

8. Полное собрание законов Российской империи. Собрание II (далі - ПСЗРИ.ІІ). 1844. СПб., 1845. - Т.XIX. - № 18526.

9. ПСЗРИ.ІІ. Т.ХХХІV. 1859. - СПб., 1860. - № 54535.

10. Положение крестьян и крестьянское движение в Бессарабии. 1812-1861 гг. Сб. Документов. - Ч. 2 // История Молдавии: Документы и материалы. - Кишинев, 1969. - Т. III. 11. Російський державний військово-історичний архів. - Ф. 4л. - Оп. 138. - Спр. 87.

\section{References:}

1. Bur'yanov, A. Istoriko-statisticheskoye opisaniye tserkvi i prikhoda seleniya Volontirovki, byvshey kazach'yey stanitsy Akkermanskogo uyezda. Kishinevskiye eparkhial'nyye vedomosti. 1877. № 20. [in Russian]

2. Derzhavnyy arkhiv Odes'koyi oblasti (The State Archives of the Odessa region (Ukraine)). F. 1. Op 218 (1831). Spr. 8. [in Russian]

3. Derzhavnyy arkhiv Odes'koyi oblasti (The State Archives of the Odessa region (Ukraine)). F. 1. Op 218 (1828). Spr. 9a. [in Russian]

4. Derzhavnyy arkhiv Odes'koyi oblasti (The State Archives of the Odessa region (Ukraine)). F. 1. Op 218 (1832). Spr. 4. [in Russian]

5. Komunal'na ustanova «Izmayil's'kyy arkhiv» («Izmail Archive»communal institution (Ukraine)). F. 755. Op. 1. Spr. 98. [in Russian]

6. Natsional'nyy arkhiv Respubliky Moldovy (The National Archive of the Republic of Moldova).

F. 1048. Op.1. Spr. 150. [in Russian]

7. Tsentral'nyy derzhavnyy istorychnyy arkhiv v m.Kyyiv (Central State Historical Archives of Ukraine in Kyiv), F.245.Op.1. [in Russian]

8. Polnoye sobraniye zakonov Rossiyskoy imperii. Sobraniye II (PSZRI.II). 1844. SPb., 1845.

T. XIX. №18526. [in Russian]

9. PSZRI.II. T. XXXIV. 1859. SPb., 1860. № 54535. [in Russian]

10. Polozheniye krest'yan i krest'yanskoye dvizheniye v Bessarabii. 1812-1861 gg. Sb. Dokumentov. Ch. 2. Istoriya Moldavii: Dokumenty i materialy. Kishinev, 1969. T. III. [in Russian] 11. Rosiys'kyy derzhavnyy viys'kovo-istorychnyy arkhiv (Russian Central State Military Historical Archive (Russia)). F. 41. Op. 138. Spr. 87. [in Russian]

Отримано:02.12.2020 p. 